
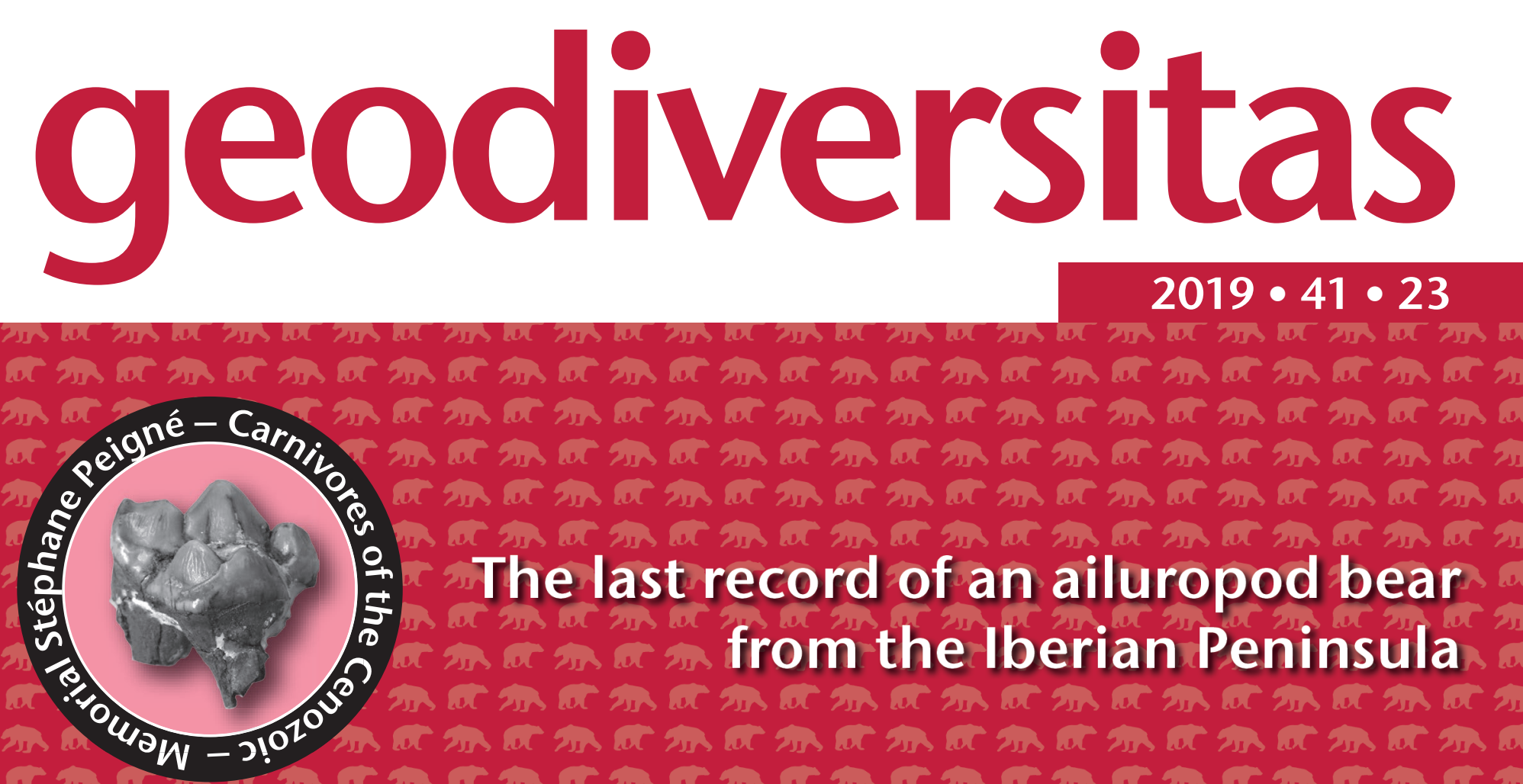

\title{
The last record of an ailuropod bear from the Iberian Peninsula
}

\author{
Juan ABELLA, \\ Daniel HONTECILLAS, \\ Alberto VALENCIANO, \\ Plinio MONTOYA, \\ Jorge MORALES, \\ María Dolores PESQUERO \& \\ Luis ALCALÁ
}

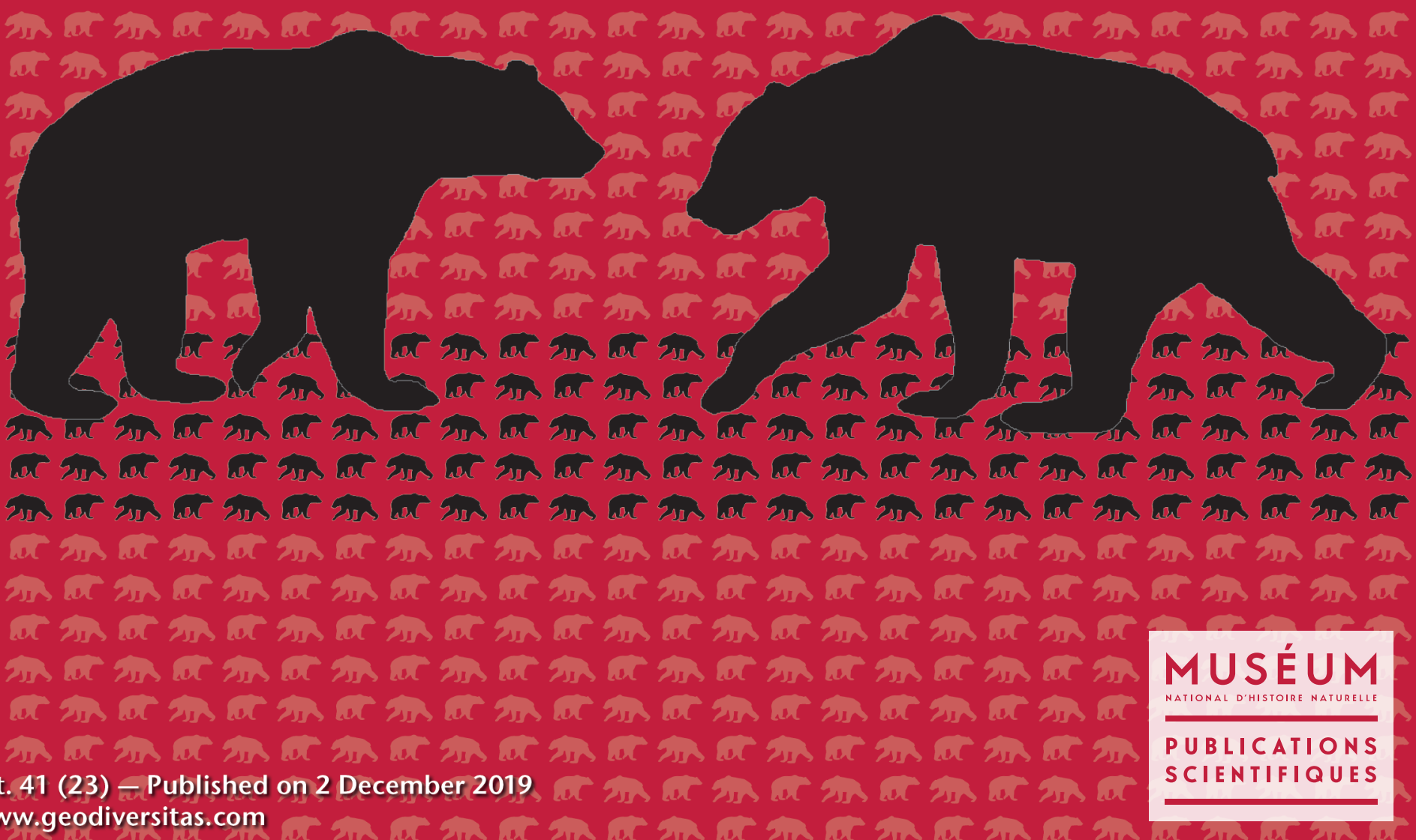


DiRECTEUR DE LA PUBLICATION: Bruno David,

Président du Muséum national d'Histoire naturelle

RÉdACTEUR EN CHEF / EDITOR-IN-CHIEF: Didier Merle

ASSISTANTS DE RÉDACTION / AsSISTANT EDITORS: Emmanuel Côtez (geodiv@mnhn.fr); Anne Mabille

Mise EN PAGE / PAGE LAYOUT: Emmanuel Côtez

COMITÉ SCIENTIFIQUE / SCIENTIFIC BOARD:

Christine Argot (MNHN, Paris)

Beatrix Azanza (Museo Nacional de Ciencias Naturales, Madrid)

Raymond L. Bernor (Howard University, Washington DC)

Alain Blieck (chercheur CNRS retraité, Haubourdin)

Henning Blom (Uppsala University)

Jean Broutin (UPMC, Paris)

Gaël Clément (MNHN, Paris)

Ted Daeschler (Academy of Natural Sciences, Philadelphie)

Bruno David (MNHN, Paris)

Gregory D. Edgecombe (The Natural History Museum, Londres)

Ursula Göhlich (Natural History Museum Vienna)

Jin Meng (American Museum of Natural History, New York)

Brigitte Meyer-Berthaud (CIRAD, Montpellier)

Zhu Min (Chinese Academy of Sciences, Pékin)

Isabelle Rouget (UPMC, Paris)

Sevket Sen (MNHN, Paris)

Stanislav Štamberg (Museum of Eastern Bohemia, Hradec Králové)

Paul Taylor (The Natural History Museum, Londres)

COUVERTURE / COVER:

Made from the Figures of the article.

Geodiversitas est indexé dans / Geodiversitas is indexed in:

- Science Citation Index Expanded (SciSearch ${ }^{\circledR}$ )

- ISI Alerting Services ${ }^{\circledR}$

- Current Contents ${ }^{\circledR}$ / Physical, Chemical, and Earth Sciences ${ }^{\circledR}$

- Scopus ${ }^{\circledR}$

Geodiversitas est distribué en version électronique par / Geodiversitas is distributed electronically by:

- BioOne ${ }^{\circledR}$ (http://www.bioone.org)

Les articles ainsi que les nouveautés nomenclaturales publiés dans Geodiversitas sont référencés par / Articles and nomenclatural novelties published in Geodiversitas are referenced by:

- ZooBank ${ }^{\circledR}$ (http://zoobank.org)

Geodiversitas est une revue en flux continu publiée par les Publications scientifiques du Muséum, Paris Geodiversitas is a fast track journal published by the Museum Science Press, Paris

Les Publications scientifiques du Muséum publient aussi / The Museum Science Press also publish:

Adansonia, Zoosystema, Anthropozoologica, European Journal of Taxonomy, Naturae, Cryptogamie sous-sections Algologie, Bryologie, Mycologie.

Diffusion - Publications scientifiques Muséum national d'Histoire naturelle

CP $41-57$ rue Cuvier F-75231 Paris cedex 05 (France)

Tél. : 33 (0)1407948 05 / Fax: 33 (0)14079 3840

diff.pub@mnhn.fr / http://sciencepress.mnhn.fr

(C) Publications scientifiques du Muséum national d'Histoire naturelle, Paris, 2019

ISSN (imprimé / print): 1280-9659/ ISSN (électronique / electronic): 1638-9395 


\section{The last record of an ailuropod bear from the Iberian Peninsula}

Juan ABELLA

Institut Català de Paleontologia Miquel Crusafont, Universitat Autònoma de Barcelona, c/ Columnes s/n, Campus de la UAB, 08193 Cerdanyola del Vallès, Barcelona (Spain) and Instituto Nacional de Biodiversidad,

Pje. Rumipamba N. 341 y Av. de los Shyris (Parque La Carolina) Quito (Ecuador) juan.abella@icp.cat (corresponding author)

Daniel HONTECILLAS

Departamento de Paleobiología, Museo Nacional de Ciencias Naturales-CSIC, C/José Gutiérrez Abascal, 2, 28006 Madrid (Spain) daniel.hontecillastamayo@gmail.com

Alberto VALENCIANO P.O. Box 61, Cape Town (South Africa) and Department of Biological Sciences, University of Cape Town, Palaeobiological Research Group, Private Bag X3, Rhodes Gift 7701, Cape Town (South Africa) alb3rtovv@gmail.com

Plinio MONTOYA

Departament de Botànica i Geologia, Àrea de Paleontologia, Universitat de València, Doctor Moliner 50, 46100 Burjassot, València (Spain) plinio.montoya@uv.es

Jorge MORALES

Departamento de Paleobiología, Museo Nacional de Ciencias Naturales-CSIC, C/José Gutiérrez Abascal, 2, 28006 Madrid (Spain) mcnm166@mncn.csic.es

María Dolores PESQUERO

Departamento de Paleobiología, Museo Nacional de Ciencias Naturales-CSIC, C/José Gutiérrez Abascal, 2, 28006, Madrid (Spain) and Fundación Conjunto Paleontológico de Teruel-Dinópolis \& Museo Aragonés de Paleontología, Avda. Sagunto s/n, 44002 Teruel (Spain) pesquero@fundaciondinopolis.org

Luis ALCALÁ

Fundación Conjunto Paleontológico de Teruel-Dinópolis \& Museo Aragonés de Paleontología, Avda. Sagunto s/n, 44002 Teruel (Spain) alcala@dinopolis.com

Submitted on 1 January 2019 | accepted on 3 June 2019 | published on 2 December 2019

urn:Isid:zoobank.org:pub:4174E526-4A7D-4D2E-9233-6FD43F145F07

Abella J., Hontecillas D., Valenciano A., Montoya P., Morales J., Pesquero M. D. \& Alcalá L. 2019. - The last record of an ailuropod bear from the Iberian Peninsula, in Bonis L. de \& Werdelin L. (eds), Memorial to Stéphane Peigné: Carnivores (Hyaenodonta and Carnivora) of the Cenozoic. Geodiversitas 41 (23): 797-809. https://doi.org/10.5252/geodiversitas2019v41a23. http://geodiversitas.com/41/23 


\section{KEY WORDS \\ Ursidae, \\ Ailuropodinae, \\ Late Miocene, \\ Las Casiones, \\ Teruel Basin.}

MOTS CLÉS

Ursidae

Ailuropodinae,

Miocène supérieur,

Las Casiones,

Teruel Basin.

\begin{abstract}
In this paper we describe Late Miocene (MN13) remains of the genus Indarctos Pilgrim, 1913 from the locality of Las Casiones (Teruel, Spain). Although the phylogenetic relationships of this genus are still controversial, the most recent phylogenetic analyses, based on cranial, mandibular and dental characters, include it in Ailuropodinae, thus making the relatives of the giant panda the predominant bears in the carnivoran assemblages for most of the Late Miocene in the Iberian Peninsula. These fossils of Indarctos punjabiensis (Lydekker, 1884) represent the last population of this subfamily from the Iberian fossil record, and possibly also from Europe, making this an important advance in our knowledge of the evolutionary history of this group. We also note the replacement of Indarctos by Agriotherium A. Wagner, 1837 in Iberian faunas, between $c .6 .3$ and $c .6 .23 \mathrm{Ma}$.
\end{abstract}

\section{RÉSUMÉ}

Le dernier enregistrement d'un ours ailuropode dans la péninsule Ibérique.

Dans cet article nous décrivons les restes fossiles du genre Indarctos Pilgrim, 1913 du Miocène supérieur (MN13) de la localité de Las Casiones (Teruel, Espagne). Bien que les relations phylogénétiques de ce genre soient encore controversées, dans l'analyse phylogénétique la plus récente basée sur les caractères crâniens, mandibulaires et dentaires, ils sont inclus dans les Ailuropodinae. Ces parents des pandas géants étaient donc les ours prédominants dans les assemblages de carnivores pendant la majeure partie du Miocène supérieur de la péninsule Ibérique. D’autre part, ces fossiles d'Indarctos punjabiensis (Lydekker, 1884) représentent la dernière population de cette sous-famille dans les archives fossiles de la péninsule Ibérique, et éventuellement aussi d'Europe, ils contribuent de manière significative à l'avancement de la connaissance de l'histoire évolutive de cet groupe. En outre, nous signalons le remplacement de Indarctos par Agriotherium Wagner, 1837 dans les faunes ibériques entre 6.3 et $6.23 \mathrm{Ma}$.

\section{INTRODUCTION}

The Late Turolian (or Ventian, sensu Morales et al. 2013) fossil locality of Las Casiones, MN13 of the European Continental Neogene Mammal zonation (Mein 1990; Bruijn et al. 1992), is located $10 \mathrm{~km}$ north of the city of Teruel (Spain) in the district of Villalba Baja, on one of the slopes of a wide ravine near the villages of Celadas and Villalba Baja; more accurately at $40^{\circ} 26^{\prime} 10^{\prime} \mathrm{N}$, 1³'58”W (Alcalá 1994; van Dam et al. 2001; Pesquero 2003) (Fig. 1). This locality is included in the local zone M2 of van Dam (1997), and an age of 6.3 Ma has been proposed (van Dam et al. 2006: suppl. notes; Gibert et al. 2013). The fossils are found in a series of levels of lacustrine origin, mostly composed of green and black clays, with occasional intercalations of fine sand (Pesquero 2003). At least two different levels can be distinguished: Las Casiones (KS) and Las Casiones Superior (KSS), the first of which is the one that has yielded the majority of fossil remains. Several papers have been already written about this locality and its faunal composition. Its geology and stratigraphy was studied by Alcalá (1994) and later by Pesquero (2003), where a more detailed model was proposed.

The latest mammal faunal composition of Las Casiones (KS) is the following: The murids Stephanomys ramblensis van de Weerd, 1976, Apodemus gudrunae van de Weerd, 1976, Occitanomys alcalai Adrover, Mein and Moissenet, 1988, cf. Rhagapodemus sp.; the cricetids Ruscinomys schaubi Villalta \& Crusafont, 1956, Cricetus cf. C. kormosi Schaub, 1930, Blancomys sanzi Adrover, Mein \& Moissenet, 1993; the glirid
Eliomys truci Mein \& Michaux, 1970; the castorid Dipoides problematicus (Schlosser, 1902); the hystricid Hystrix depereti Sen, 2001; the erinaceid Galerix sp.; the talpids Desmanella sp., Talpa sp.; the soricids Archaeodesmana sp., Paenelimnoecus sp., Blarinella sp., Amblycoptus jessiae Doukas, van den Hoek Ostende, Theocharopoulos \& Reumer, 1995; the vespertilionid chiropteran Vespertilionidae indet.; the ochotonid lagomorph Prolagus sp.; the proboscideans Tetralophodon longirostris (Kaup, 1832) and Zygolophodon turicensis (Schinz, 1824); the hyracoid Pliohyrax sp. cf. P. graecus (Gaudry, 1860); two species of the cervid Pliocervus Hilzheimer, 1922; the bovids Tragoportax sp. and two species of Boselaphini indet.; the hippopotamid Hippopotamus crusafonti Aguirre, 1963; the rhinocerotid Dihoplus schleiermacheri (Kaup, 1834); three species of the equid Hipparion Christol, 1832: H. primigenium (von Meyer, 1829), H. mathewii (Abel, 1926), and H. periafricanum Villalta \& Crusafont, 1957; the mustelids Plesiogulo monspessulanus Viret, 1939, Baranogale adroveri (Petter, 1964), Mustela sp., and a Mustelidae indet. aff. Sabadellictis sp.; the ursid Indarctos punjabiensis (Lydekker, 1884); the hyaenids Plioviverrops sp. cf. P. guerini (Villalta \& Crusafont, 1948) and Thalassictis hipparionum (Gervais, 1859); and the felids Paramachaerodus orientalis Kittl, 1887, Amphimachairodus giganteus Kretzoi, 1929, Metailurus major Zdansky, 1924, Pristifelis attica Wagner, 1857, and Felinae indet. (Cerdeño 1989; Alcalá 1994; Alcalá et al. 1994; van Dam 1997; Alcalá \& Montoya 1998a, b; Pesquero 2003; van Weers \& Rook 2003; Salesa et al. 2012). 


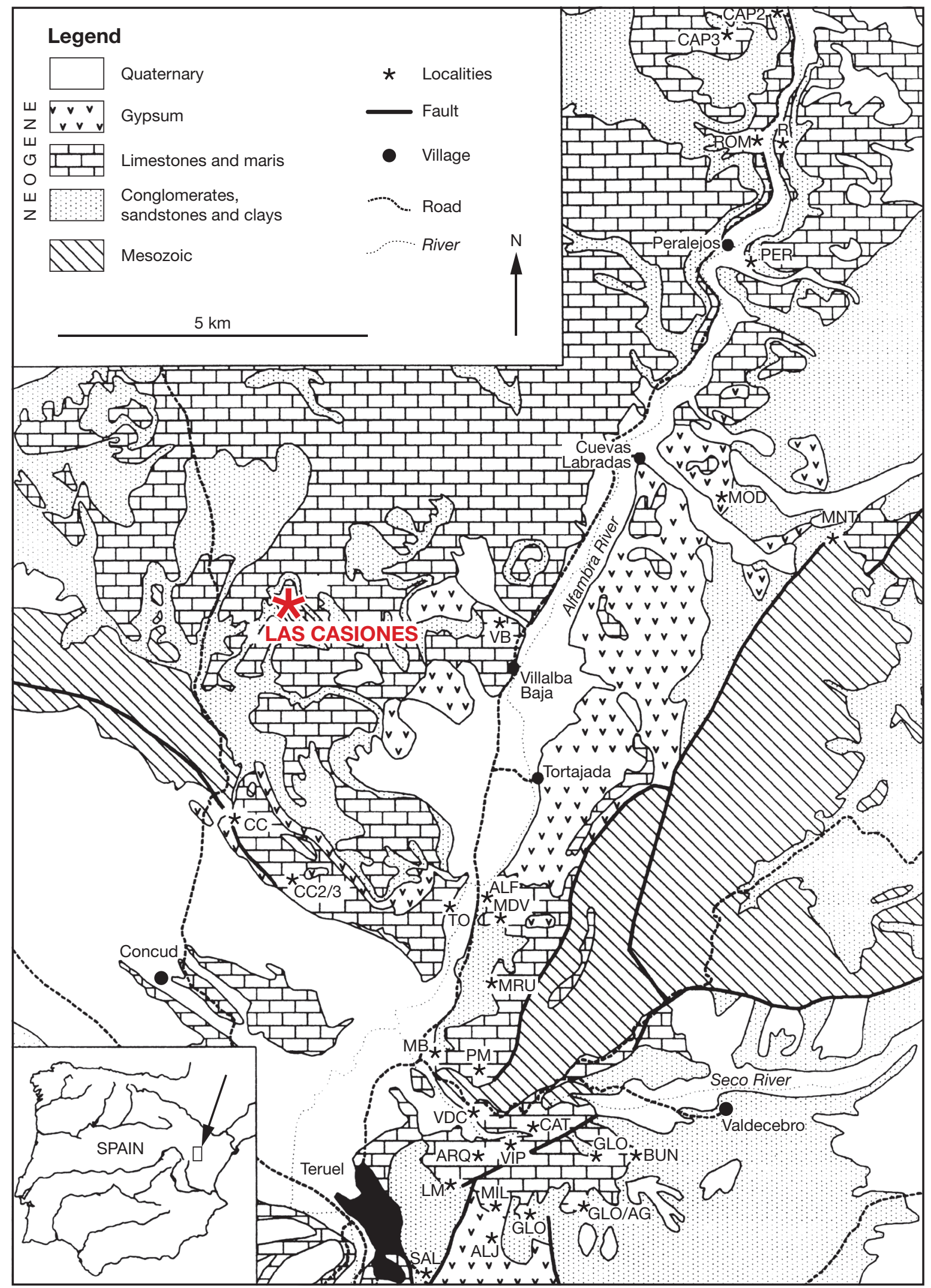

FIG. 1. - Schematic geologic map of the northern part of the Teruel basin with the paleontological localities indicated (after Pesquero et al. 2003 modified). 
TABLE 1. - Measurements (in $\mathrm{mm}$ ) of the dentition of the specimens of the genus Indarctos Pilgrim, 1913 from Las Casiones (length $\times$ width).

\begin{tabular}{lcccc}
\hline Specimens & P2 & P4 & M1 & M2 \\
\hline K-174 & $10.45 \times 7.42$ & - & - & - \\
K94-1733 & - & $32.01 \times 22.51$ & - & - \\
K-162 & - & - & $29.21 \times 28.98$ & - \\
K-161 & - & - & $\times 26.89$ & - \\
KS-4316 & - & - & $28.62 \times 27.01$ & - \\
KS-4315 & - & - & - & $31.34 \times 27.79$ \\
KS-4317 & - & - & - & $31.49 \times 28.06$ \\
\hline
\end{tabular}

The assignment of the bear fossil remains from Las Casiones to the genus Indarctos Pilgrim, 1913 might be considered as a novelty, since Alcalá (1994) described as Agriotherium Wagner, 1837 a very worn M1 and a fragment of M1, due to their large width. This identification has subsequently been repeated in many papers. The presence of Indarctos in Las Casiones was also tentatively noted by both Alcalá $e t$ al. (2005) and Salesa et al. (2012). This change in taxonomic determination has been possible due to the recovery of the new diagnostic remains described in this paper.

\section{THE GENUS INDARCTOS IN THE FOSSIL RECORD}

The genus Indarctos comprises medium to large-sized bears from the late Miocene, with an omnivorous diet (Montoya et al. 2001; Viranta 2004; Abella 2011; Abella et al. 2013; Monescillo et al. 2014; Domingo et al. 2016). Although comprehensively studied, there is not a full consensus about their phylogenetic relationships. Some authors (Hendey 1972; Qiu et al. 2014) relate them to the genus Agriotherium (considered a Hemicyonidae by the authors of the present paper) and others consider it to be a basal Ursidae (Abella et al. 2012, 2014). However, the most recent phylogenetic analyses, based on cranial, mandibular and dental characters, include Indarctos spp. in the Ailuropodinae (Abella et al. 2012; Qiu et al. 2014). This genus was indeed the predominant bear taxon during most of the late Miocene in the Northern Hemisphere (Abella et al. 2014).

The first specimen currently referred to the genus Indarctos consists of a left mandible fragment from the Greek locality of Pikermi identified as Hyaenarctos sp. by Dames (1883), with Weithofer (1888) later referring it to $H$. atticus. However, in 1884 Lydekker created the species $H$. punjabiensis based on a broken maxilla (which included P4-M1) from the Siwaliks in India. In that paper he also assigned a maxilla with P4-M2 and a skull with Upper canine and P4-M2 from other localities to the same genus. The latter specimen has been the cause of most of the later taxonomic confusion in comparisons among species since this skull clearly can be assigned to the genus Agriotherium, due to the lack of a clear talon and different relative development of the main cusps in the M2.

Pilgrim (1913) moved some of these remains from the junior synonym genus Hyaenarctos (also later synonym of Agriotherium) to the newly created genus Indarctos based on a maxillary fragment with M2 and broken M1 from the Siwa- liks. However, it was not until a year later (Pilgrim 1913) that he measured, figured and compared this specimen to other, similar fossils, describing Indarctos salmontanus as the type species of the genus (Pilgrim, 1914). Later Baryshnikov (2002) accepted only two species of the genus Indarctos, literally he stated: "The genus Indarctos comprises two species. I. arctoides (Depéret, 1895) was found in Europe, northern Africa and Turkey, dating as the Vallesian (MN 9-11). I. punjabiensis (Lydekker, 1884) known from the Turolian (MN 10-13) had a Holarctic range, occurring in Europe, northern Africa, in the central, southern and eastern parts of Asia, and in North America”. Therefore, although indirectly, he synonymized Pilgrim's type species with Indarctos punjabiensis.

The oldest record of Indarctos comprises some specimens from MN9 in the Vallesian basin of Vallès-Penedès, at the localities of Can Porull (Villalta \& Crusafont 1943, 1948) and later from Can Llobateres (Crusafont \& Kurtén 1976). These remains were assigned to Indarctos vireti Villalta \& Crusafont, 1943, a small sized member of the genus, with elongated molars, more primitive (less reduced) premolars, and well-developed diastemas between them.

Indarctos arctoides (Depéret, 1895), is documented from MN10. This species was first described from the French locality of Montredon, and can be found along the northern edge of the Mediterranean Sea, including Spain, France and Turkey (Tobien 1955; Geraads et al. 2005; Abella 2011; Abella et al. 2014).

Finally, Indarctos punjabiensis (incl. I. atticus) has an extensive record in the Iberian Peninsula from MN10 to MN12. Most of these specimens were studied in detail by Montoya et al. (2001). Following the arguments of that paper we accept three species of Indarctos; four, if we take include the peculiar I. anthracites (Weithofer, 1889), which is thought to be an insular form and is only represented by a single published specimen. These are I. vireti, I. arctoides and I. punjabiensis with the last species having the temporal range. The present study increases the stratigraphic range of the genus Indarctos in the Iberian Peninsula to the lower part of MN13.

\section{MATERIAL AND METHODS}

The fossil remains of Indarctos punjabiensis from Las Casiones are part of the collections of the Gobierno de Aragón (Spain), and are housed at the Museo Aragonés de Paleontología, Fundación Conjunto Paleontológico de Teruel-Dinópolis (Teruel, Spain). The studied material was: KS-30: right IV metacarpal; K-162: left M1; K-161: distal fragment of right M1; KS-4315: right M2; KS-4316: left M1; KS-4317: left M2; K94-1733: right P4; K-174: maxillary fragment (P2, root of $\mathrm{P} 1$ and $\mathrm{P} 3)$; KS-4314: premolar (p3?) (Figs 2; 3). Of the fossil remains studied here, only M1 K-161 and K-162 were originally described in Alcalá (1994). For comparison, we studied the the upper dentition of Indarctos vireti housed at the Institut Català de Paleontologia- Miquel Crusafont Museu (since the holotype consists of a mandible fragment with $\mathrm{p} 4-\mathrm{m} 2$ ), cast specimens of Indarctos arctoides (paratype) from Montredon housed in the Natural History Museum Basel - Naturhistorisches Museum 
A

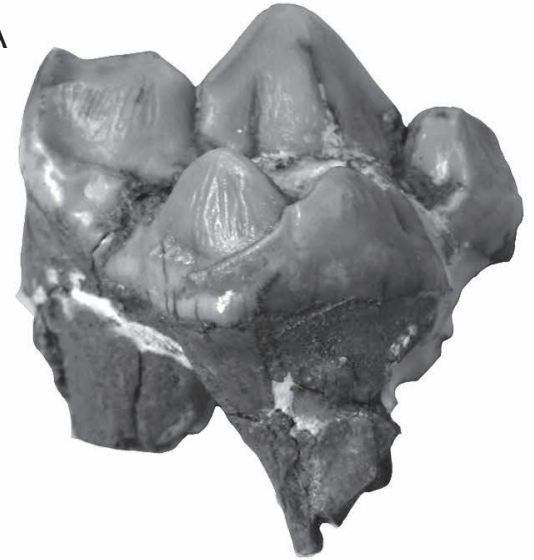

C

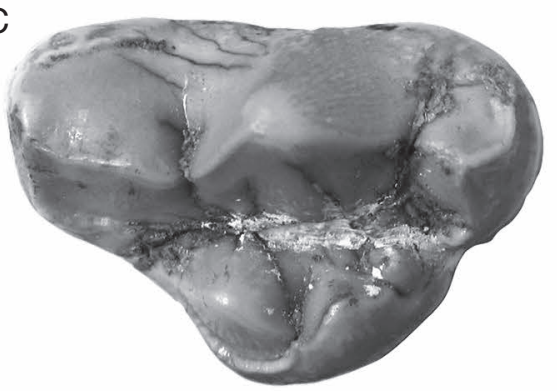

I

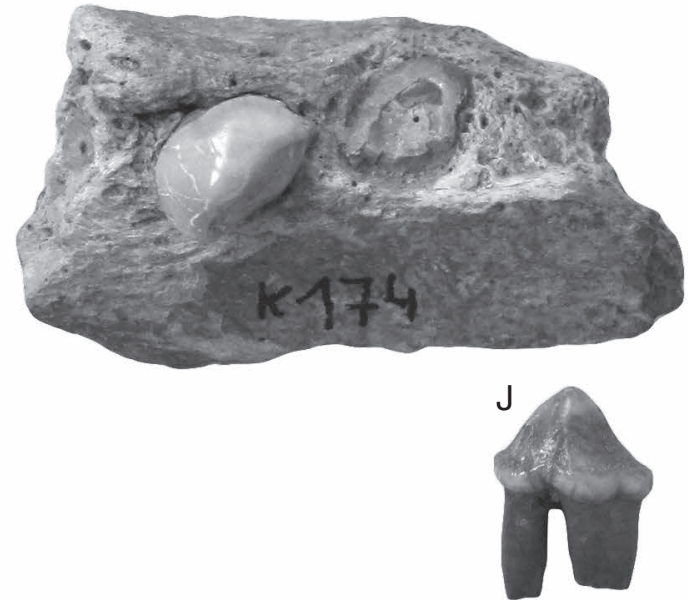

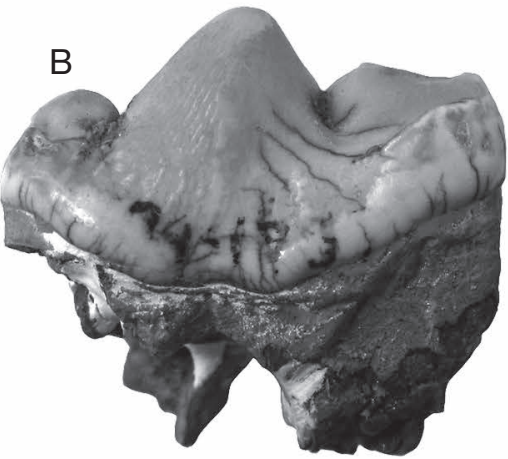
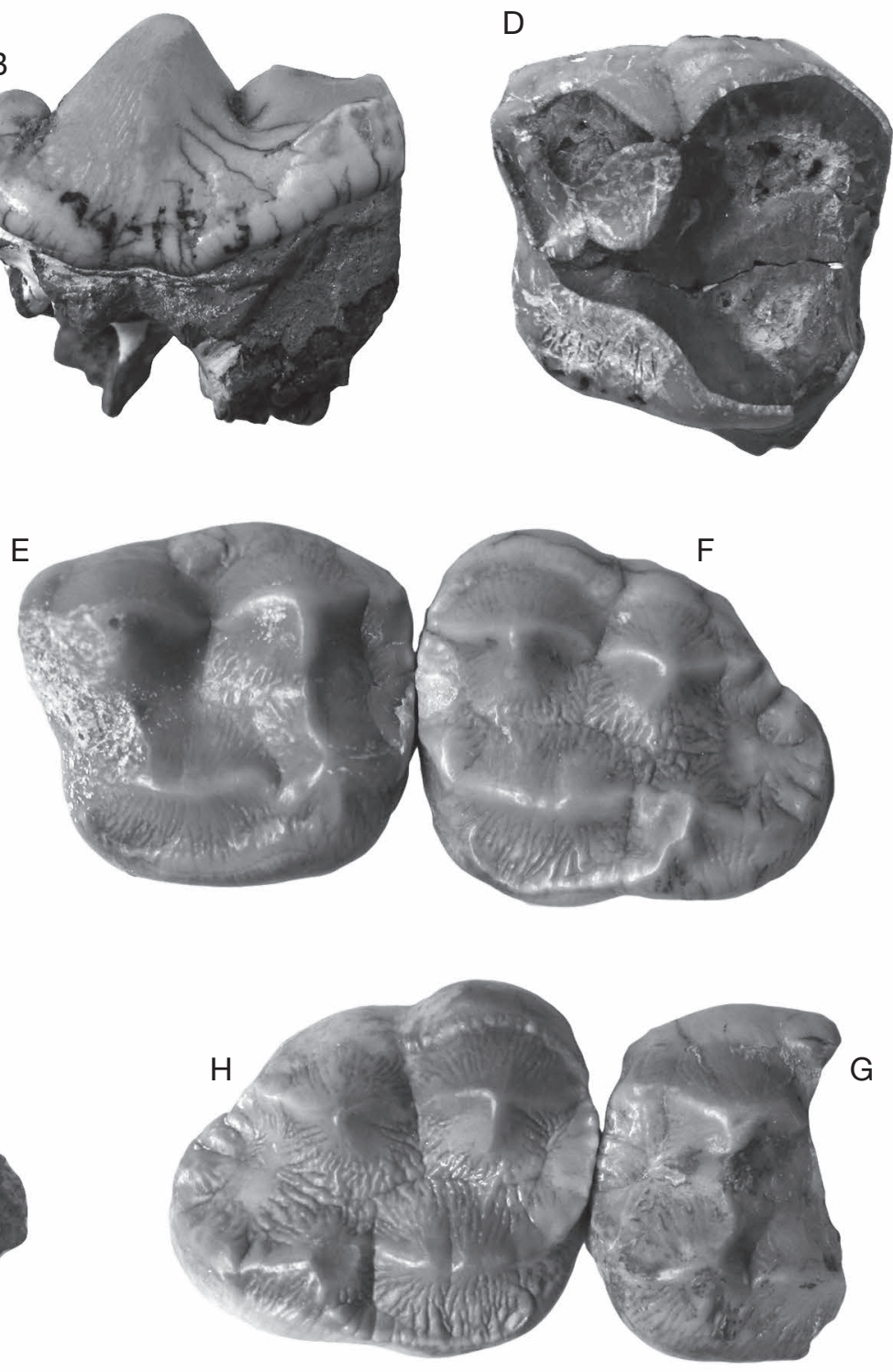

$\mathrm{G}$

FlG. 2. - Indarctos punjabiensis (Lydekker, 1884) from Las Casiones: A-C, K94-1733, right P4: A, lingual view; B, labial view; C, occlusal view; D, K-162, left M1, occlusal view; E, KS-4316, left M1, occlusal view; F, KS-4317, left M2, occlusal view; G, K-161, distal fragment of right M1, occlusal view; H, KS-4315, right M2, occlusal view; I, K-174, left maxillary fragment with P2 and root of P1 and P3 (occlusal view); J, lower premolar, labial view. Scale bar: $5 \mathrm{~cm}$.

Basel, the sample of $I$. arctoides housed at Museo Nacional de Ciencias Naturales-CSIC in Madrid, and the cast of the holotype of I. punjabiensis housed at the British Museum of Natural History, London.

The measurements were taken using Mitutoyo Absolute digital calipers to the nearest $0.1 \mathrm{~mm}$ (Table 1).

INSTITUTIONAL ABBREVIATIONS

$\mathrm{KS}$ and $\mathrm{K}$ Las Casiones;

MNCN Museo Nacional de Ciencias Naturales;

NMB Natural History Museum Basel - Naturhistorisches
Museum Basel;

ICP Institut Català de Paleontologia - Miquel Crusafont Museu.

SYSTEMATIC PALEONTOLOGY

Order CARNIVORA Bowdich, 1821

Suborder CANIFORMIA Kretzoi, 1943

Infraorder ARCTOIDEA Flower, 1869

Parvorder URSIDA Tedford, 1976

Superfamily URSOIDEA Fischer von Waldheim, 1817 
A

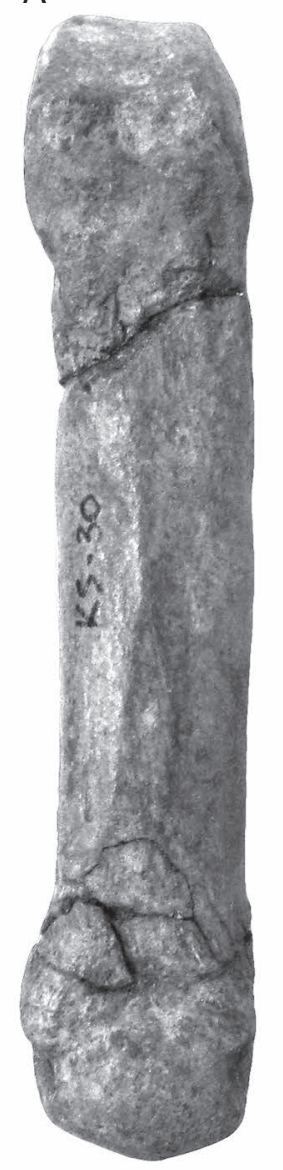

$\mathrm{B}$

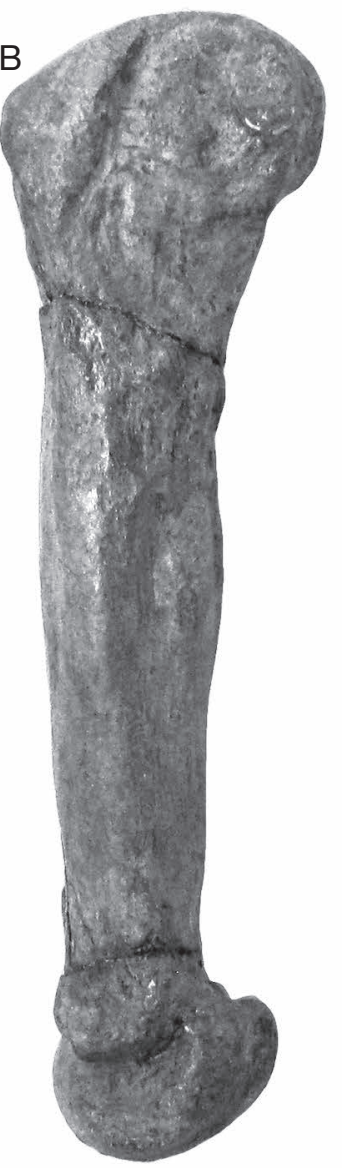

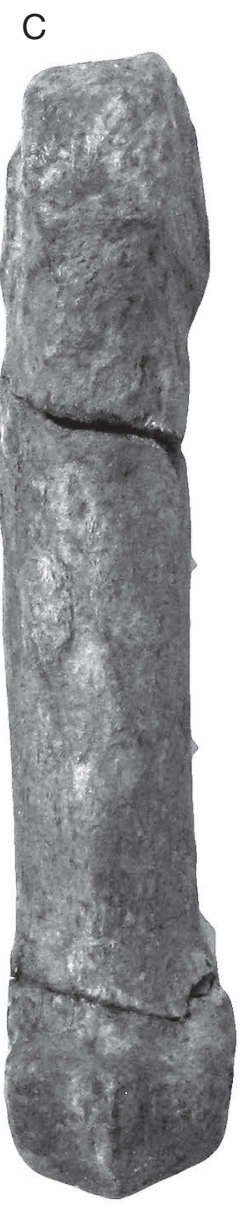

D

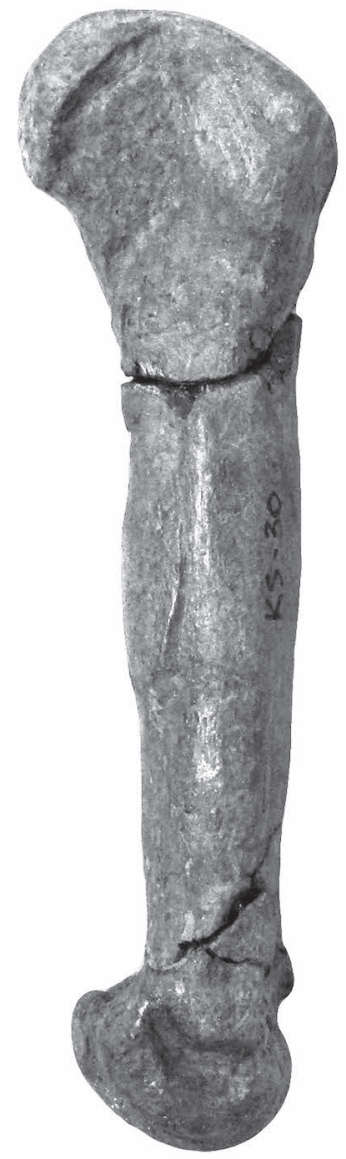

FIG. 3. - Indarctos punjabiensis (Lydekker, 1884) from Las Casiones, right IV metacarpal: A, plantar view; B, medial view; C, dorsal view; D, lateral view. Scale bar: $5 \mathrm{~cm}$.

Family UrsidAE Fischer von Waldheim, 1817

Subfamily AILUROPODINAE Grevé, 1894

Tribe InDARCTINI Abella, Alba, Robles, Valenciano,

Rotgers, Carmona, Montoya \& Morales, 2012

Genus Indarctos Pilgrim, 1913

\section{Indarctos punjabiensis (Lydekker, 1884)}

Hyaenarctos punjabiensis Lydekker, 1884: 226.

Agriotherium cf. A. roblesi - Alcalá 1994: 103, 104, pl. 3, fig. o.

SYNTYPE. - Fragments of the left and right maxillae with P4-M1, figured by Lydekker (1884: pl. XXX, fig. 2).

TYPE LOCALITY. — Hasnot Siwaliks. Salt Range, Jhelum District. Punjab.

AGE. — Late Miocene. MN 10-13.

EMENDED DIAGNOSIS. - Medium to large sized Ursidae, with marked sexual dimorphism. Plantigrade. Dolichocephalic skull, base of the zygomatic arch coincides with the M1 and the mesial part of M2. The premolars are smaller in relative size and number compared to the other members of the genus, being crowded to some degree. Both the P2 and the P3 are double rooted, with the tendency to be fused in some individuals. The mesio-distal length of the P4 is equal to that of M1, and it has a quite developed parastyle, with two crists, une lingual and one labial. Wide upper molars, almost as wide as they are long; from sub-rectangular to trapezoid in shape. The talon in M2 is large, but not as long as in the derived Ursinae. Generally low, but robust jaw. Relatively long $\mathrm{m} 1$, with equally long talonid and trigonid; tall entoconid, taller than the hypoconid; $\mathrm{m} 1$ talonid similar to that of $\mathrm{m} 2$. The $\mathrm{m} 3$ morphology varies from rounded to elongated.

\section{DESCRIPTION}

\section{Upper dentition}

The description has been carried out on the possibly associated upper dentition, using both sides when possible.

P1 (Fig. 2I). Only a single root is preserved. Smallest of the upper premolars.

P2 (Fig. 2I). Reduced, ovoid premolar, with only one root. Single cusp with two ridges, one mesial and one distal, that curve towards the lingual side; the distal cusp is blunter than the mesial one. This tooth is rotated relative to the main axis of the maxilla and somehow crowded, due to the shortening of the muzzle.

P3 (Fig. 2I). Only a single root is preserved. Larger than the preceding upper premolars. 


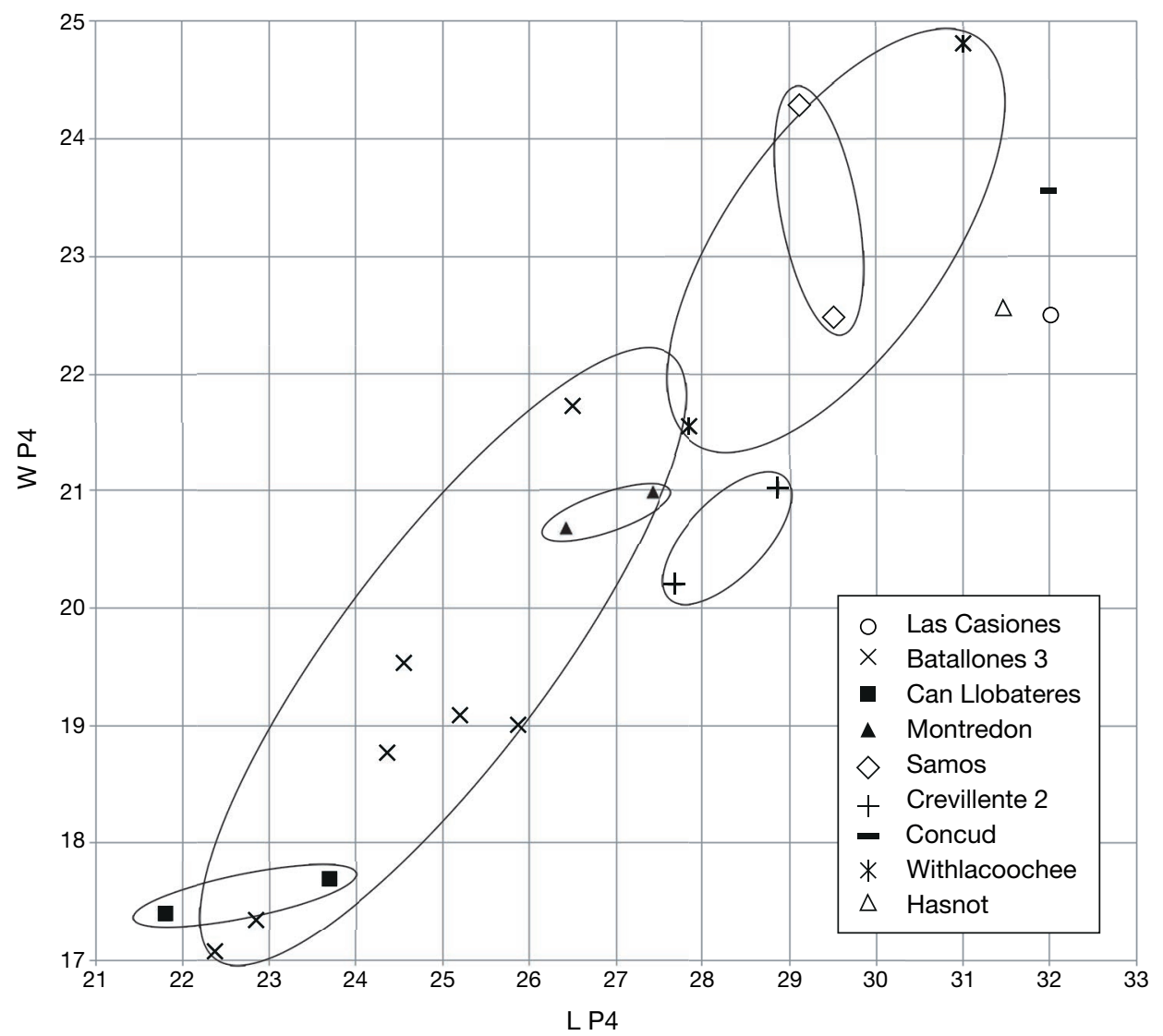

FIG. 4. - Bivariate plot of the P4 of different Indarctos Pilgrim, 1913 species from various sites.

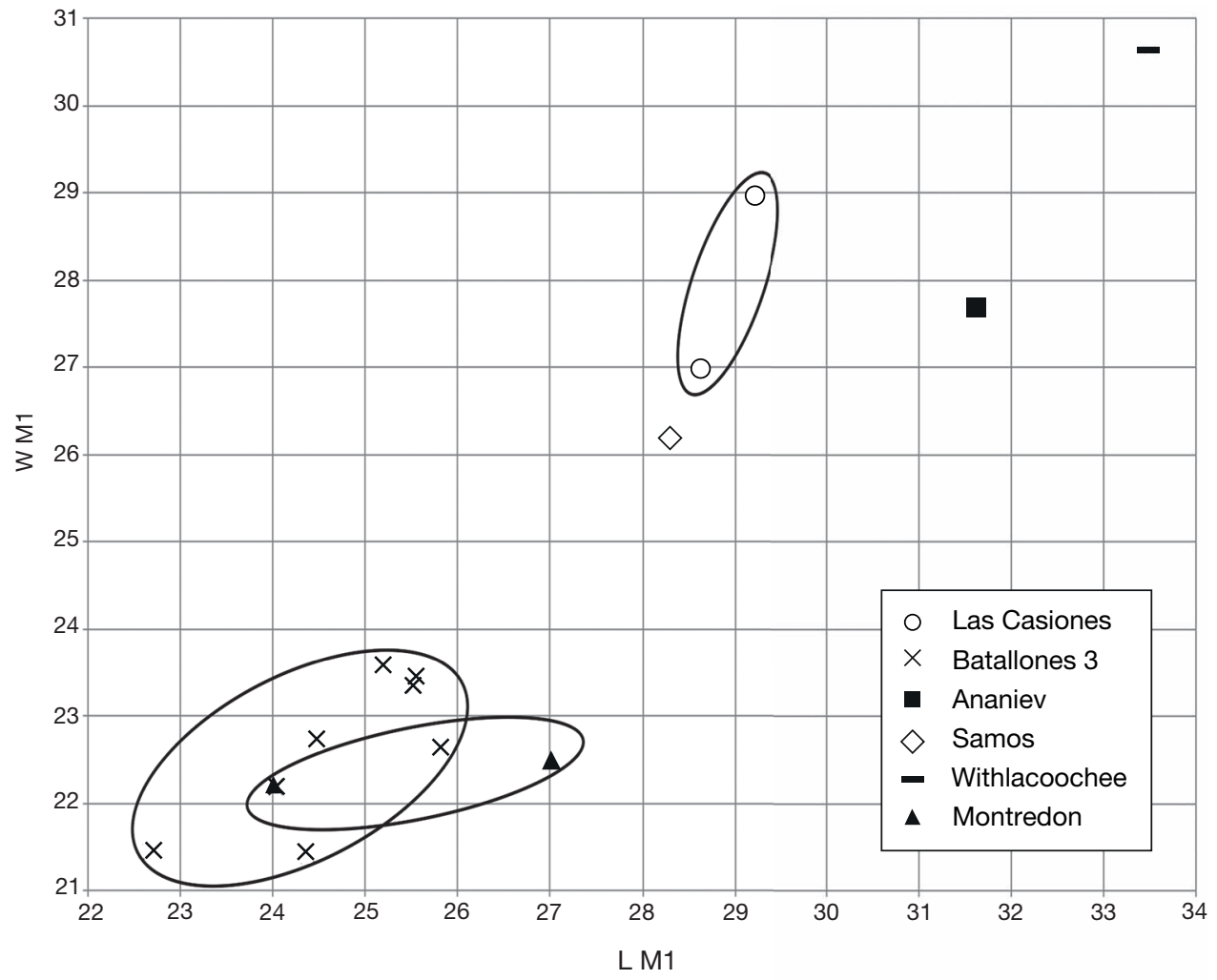

FIG. 5. - Bivariate plot of the M1 of different Indarctos Pilgrim, 1913 species from various sites. 


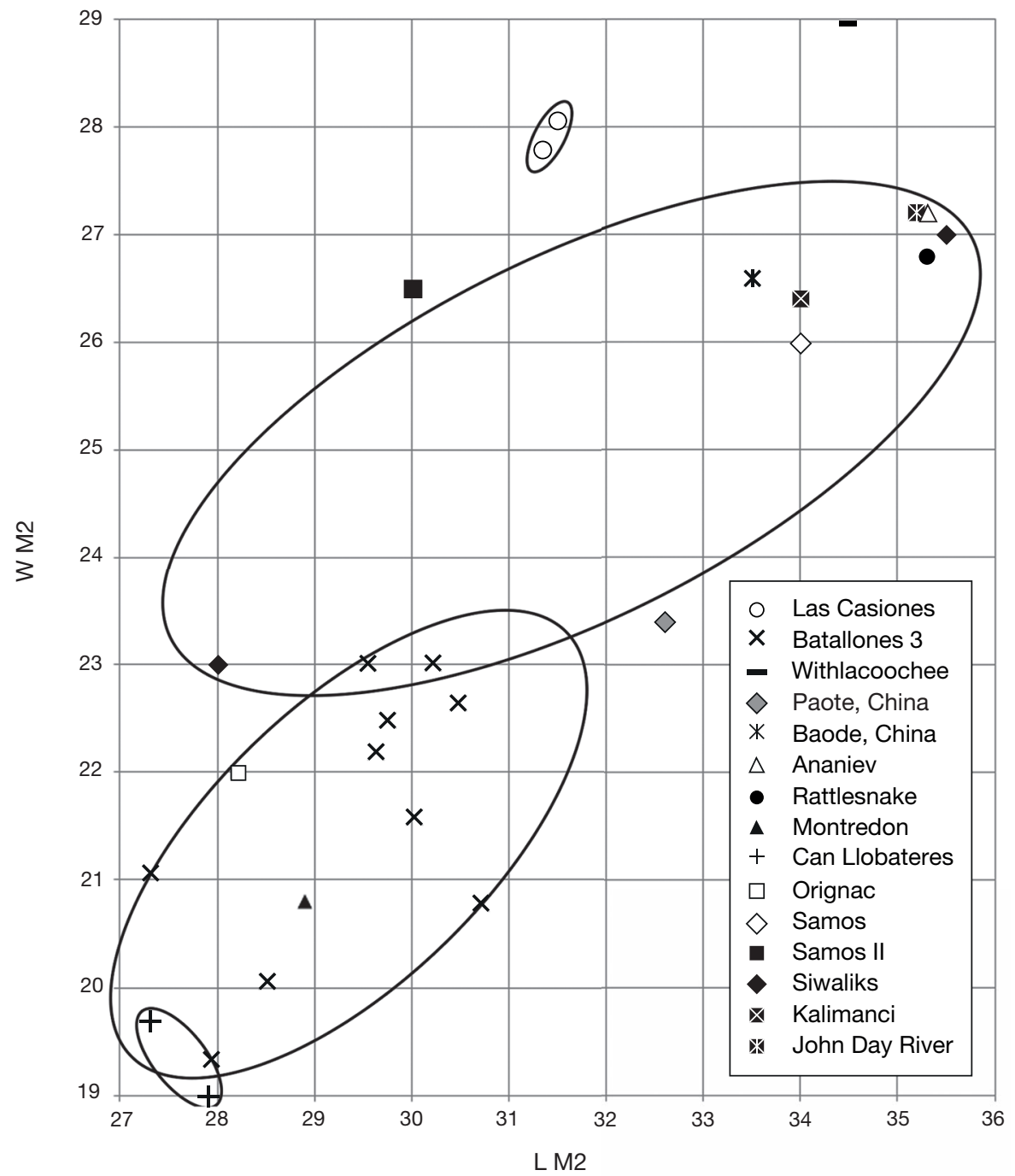

FIG. 6. - Bivariate plot of the M2 of different Indarctos Pilgrim, 1913 species from various sites.

P4 (Fig. 2A-C). Complete upper carnassial. Deeply wrinkled enamel. Well-developed parastyle with two ridges, one labial and one lingual. High paracone, almost flat in its lingual part but convex in the labial one. Metastyle lower than paracone, but more sectorial; wide at its base, with two cingula, a weak one in the labial part and a slightly more developed one in the lingual part. Where the two cingula join they create a distal pointed edge. The protocone is complex. It has three cusps, which grow taller towards its distal part, with the latter being the tallest, practically at the level of the notch between paracone and metastyle, and the only one partly surrounded by the labial cingulum of the cusp. The protocone occupies an intermediate position with respect to the paracone, and is projected lingually.

M1 (Fig. 2D). Very worn first upper molar, much more in the distal than in the mesial part. This kind of asymmetric wear is quite common in ursoids, and in this case prevents the description of many of the dental features. It is nearly square in shape. The contact facet for P4 is relatively large and concave instead of flat, while that for the M2 is located almost at the labio-distal corner of the tooth. Towards the labial side, between the paracone and the metacone, there is an expansion zone that widens towards the metacone; this structure has a slight vertical wear facet.

M1 (Fig. 2E-G). Molars with a clear quadrangular shape, almost as wide as long. The enamel has the typical young ursid roughness. It is barely worn and the roots were not completely formed before death and are not recovered. As in the worn M1, these two also have a medial-lingual thickening of the labial cingulum between the paracone and metacone. The paracone is larger (in both width and height) than the metacone. Both parastyle and metastyle are present, although these are very weak compared to the main cusps. There is a well-developed cingulum occupying almost all of the lingual face. The contact with P4 is vertical and straight. The protocone is large and cristiform. Distal to the protocone there is a robust hypocone, which is taller than the protocone, and although being the small- 

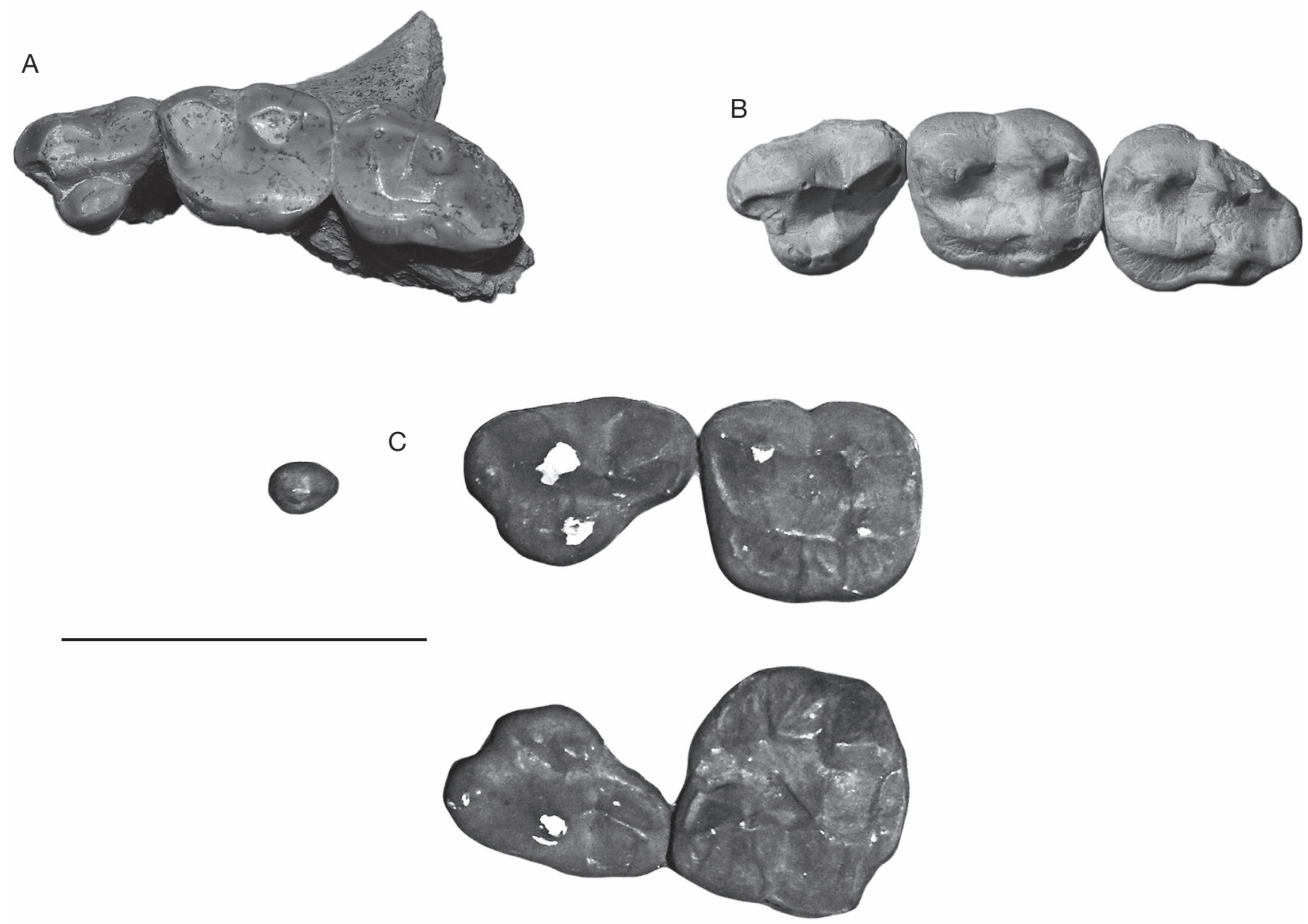

FIG. 7. - Other Indarctos species for comparison with I. punjabiensis (Lydekker, 1884) of Las Casiones: A, I. vireti Villalta \& Crusafont, 1943; B, I. arctoides (Depéret, 1895) (from type locality); C, I. punjabiensis (syntype). All images are in occlusal view. Scale bar: $5 \mathrm{~cm}$.

est of the four main cusps. Hypocone is more complex, having a ridge on each side. The mesial ridge is close to the protocone, whereas the lingual one joins the lingual cingulum. The medial one meets the ridge coming down the central valley of the tooth from the metacone and the distal ridge ends at the most distal edge of the tooth. In the labial side there is other cingulum, which is considerably thickened in the distal region.

M2 (Fig. 2F, H). A wide tooth, with large cingula on both in its labial and its lingual side, with the latter the most developed. In occlusal view the talon is slightly rotated labially while the labial cingulum is labially tilted, giving the teeth two different crushing surfaces. The tooth enamel is clearly rough, which is most evident on the lingual surface. The protocone is continued by the ridge that originates at the front of the paracone, continuing throughout the mesial part of the molar towards the lingual side, but not forming a clear parastyle. Unlike M1, the M2 protocone is slightly bilobed in its central part. The paracone is taller than the metacone although the difference is slightly smaller than in the M1. The talon is very rounded and relatively short, and although it joins the metacone, it has a more labial position. It has a ridge that runs from the hypocone to the metacone, forming a distal semicircle divided into at least six small cusps.

\section{Lower Dentition}

px (Fig. 2J). Biradicular premolar. Longer than wide. It has only one cusp in the center of the crown, with two cristids, one slightly mesio-lingual, which approaches the mesial edge, and other one distal.

\section{Postcranial skeleton}

Right Mc IV (Fig. 3). This metapodial has a robust general morphology. Epiphyses are wider than the diaphysis, the latter having a homogeneous width in dorsal view throughout its length. However, in lateral view, there is a difference in height because the distal part of the diaphysis is clearly flatter. The proximal epiphysis is robust, convex in the most proximal zone, the surface that serves as articulation for the unciform. Its contact facet for the Mc III has two lobes, a convex dorso-proximal one and a flat palmar-proximal one. The articulation for the $\mathrm{Mc} \mathrm{V}$ has also two facets, a slightly convex dorsal one and a noticeably concave palmar one. The distal epiphysis is slightly wider and somewhat rounded in its dorsal view, thus being more flattened in lateral view. 


\section{SYSTEMATIC DISCUSSION}

The fossil remains from Las Casiones show the following features in the dentition that clearly match the morphology of Indarctos:

1) A two-ridged parastyle on the P4. A mesially complex protocone;

2) Complex hypocone on M1;

3) Relatively short and robust Mc IV, with relatively large proximal and distal epiphyses that are equal in size. Medial and lateral contact facets of proximal epiphysis separate and distinct from proximal contact facet.

The fossil remains from Las Casiones are amongst the largest of the genus (Figs 4, 5 and 6), and in the Iberian Peninsula second only to the huge remains from Concud. Therefore, they are easily included in Indarctos punjabiensis, a species that was probably present in the Iberian Peninsula from MN10 and certainly from MN11: Masia la Roma 604, Terrassa, Crevillente 2, Concud, Rambla de Valdecebro 5 (Montoya et al. 2001; Alcalá et al. 2005; Abella et al. 2012, 2014).

\section{COMPARISON WITH OTHER INDARCTOS SPECIES}

Indarctos punjabiensis exhibits considerable morphological variability in the dentition, even within samples from the same site (Montoya et al. 2001), as shown by the measurements in Table 1 and the size comparison in Figures 4, 5, and 6. We can, however, distinguish it from other species of the genus on to the criteria presented below.

The remains from Las Casiones differ from Indarctos vireti (Fig. 7) in the following features (the holotype of this species is a mandible (Can Purull, Villadecavalls, Spain) so the comparison has been carried out using the upper dentition from Can Llobateres):

Overall, the dentition from Las Casiones is much larger than that of Indarctos vireti; the $\mathrm{P} 4$ of the latter is more elongated, without parastyle and much simpler in terms of the number of cusps in the protocone; the M1, although similar in cusp disposition, is more elongated in the Vallesian species, especially in the talon; the M2 is much more elongated in $I$. vireti than in the Las Casiones specimen.

The fossil remains from Las Casiones differ from the holotype of Indarctos arctoides (Montredon, France, MN10), and from the spectacular sample of Indarctos arctoides from Batallones 3 (Madrid, Spain) (Fig. 7) in the following features:

The dentition from Las Casiones is larger than that of Indarctos arctoides; the $\mathrm{P} 4$ of $I$. arctoides (same locality as the holotype) is already as wide as that of Las Casiones or relatively wider, due to the lingual widening of the wall between the paracone and metastyle; the parastyle is not as large and the protocone has fewer cusps, with only two cusps instead of the three in the P4 from Las Casiones; the M1 of both species are almost identical in shape, but the M2 from Las Casiones seems relatively much wider than that of the holotype of $I$. arctoides.

The dentition from Las Casiones is almost identical in size as that of the holotype of Indarctos punjabiensis (Hasnot Siwaliks, India. MN10-13) (Fig. 7). Both the P4 and M1 are very similar in morphology, though the paracone of $\mathrm{P} 4$ has fewer cusps in the holotype of I. punjabiensis. Comparison of the M2 from Las Casiones to that published by Pilgrim in 1914 under the name of I. salmontanus (now I. punjabiensis) leads to the conclusion that the latter is slightly more elongated, due to the lesser development of the labial and lingual cingula, but it has almost the same cusp disposition.

\section{BIOSTRATIGRAPHY}

As already mentioned, the fossil record of the genus Indarctos in the Iberian Peninsula covers much of the late Miocene. Thus, it is represented by I. vireti in the Vallesian (MN9 and MN10) of the Vallès-Penedès (Catalonia), by I. arctoides in the Vallesian (MN10) of the Batallones sites (Madrid) and by I. punjabiensis (formerly I. atticus) in the late Vallesian of Terrassa (Vallès-Penedès, Catalonia) and Masía de La Roma 604 (Teruel basin). It is also recorded from the early Turolian (MN11) of Crevillente 2 (Alicante), as well as in other Turolian (MN11 and MN12) localities from the Teruel basin. In addition, the range is now extended to the late Turolian or Ventian (MN13) also from the Teruel basin. More detailed information on the Spanish record of the genus Indarctos can be found in Montoya (1994), Montoya et al. (2001), Alcalá et al. (2005), Abella (2011) and Abella et al. (2013, 2014, 2015).

From a biostratigraphic point of view, the material of Indarctos punjabiensis in Las Casiones represents the youngest appearance of the genus in the fossil record of the Iberian Peninsula (and perhaps also of Europe), just before its replacement by the hemicyonid Agriotherium. Should be mentioned that the Indarctos record from Ananiev (Ukraine) could be more or less of the same age (Baryshnikov 2002). Recent works allow us to date, with relatively good precision, the moment of this substitution and its relationship to the faunistic events that took place during the Messinian, although prior to the Messinian Salinity Crisis.

The Las Casiones site lies within MN13, in local zone M2 of van Dam (1997), and van Dam et al. (2006: suppl. notes), where it is assigned an age $c .6 .3 \mathrm{Ma}$. In addition, it is the reference site for the so-called First African-Iberian Dispersal (Gibert et al. 2013) because it records the FAD of Hippopotamidae in Western Europe from Africa. Furthermore, the entry of eastern immigrants, such as the genus Plesiogulo and Hystrix depereti, takes place during this period.

On the other hand, the FAD of the genus Agriotherium in Europe is recorded at the Venta del Moro site (Cuenca del Cabriel, Valencia) (Morales 1984; Montoya et al. 2006), with A. roblesi Morales \& Aguirre, 1976. This deposit is located within MN13 in local zone M3, and a recent paleomagnetic study has allowed dating it to c. 6.23 Ma (Gibert et al. 2013). Because Venta del Moro also records the FAD in Europe of Paraethomys and Paracamelus, taxa most likely coming from North Africa, it is the reference site for the so-called Second African-Iberian Dispersal (Gibert et al. 2013). This dispersal coincides with the so-called 'Paraethomys event' or 'Second Messinian mammalian event' of Agustí et al. (2006) and with 


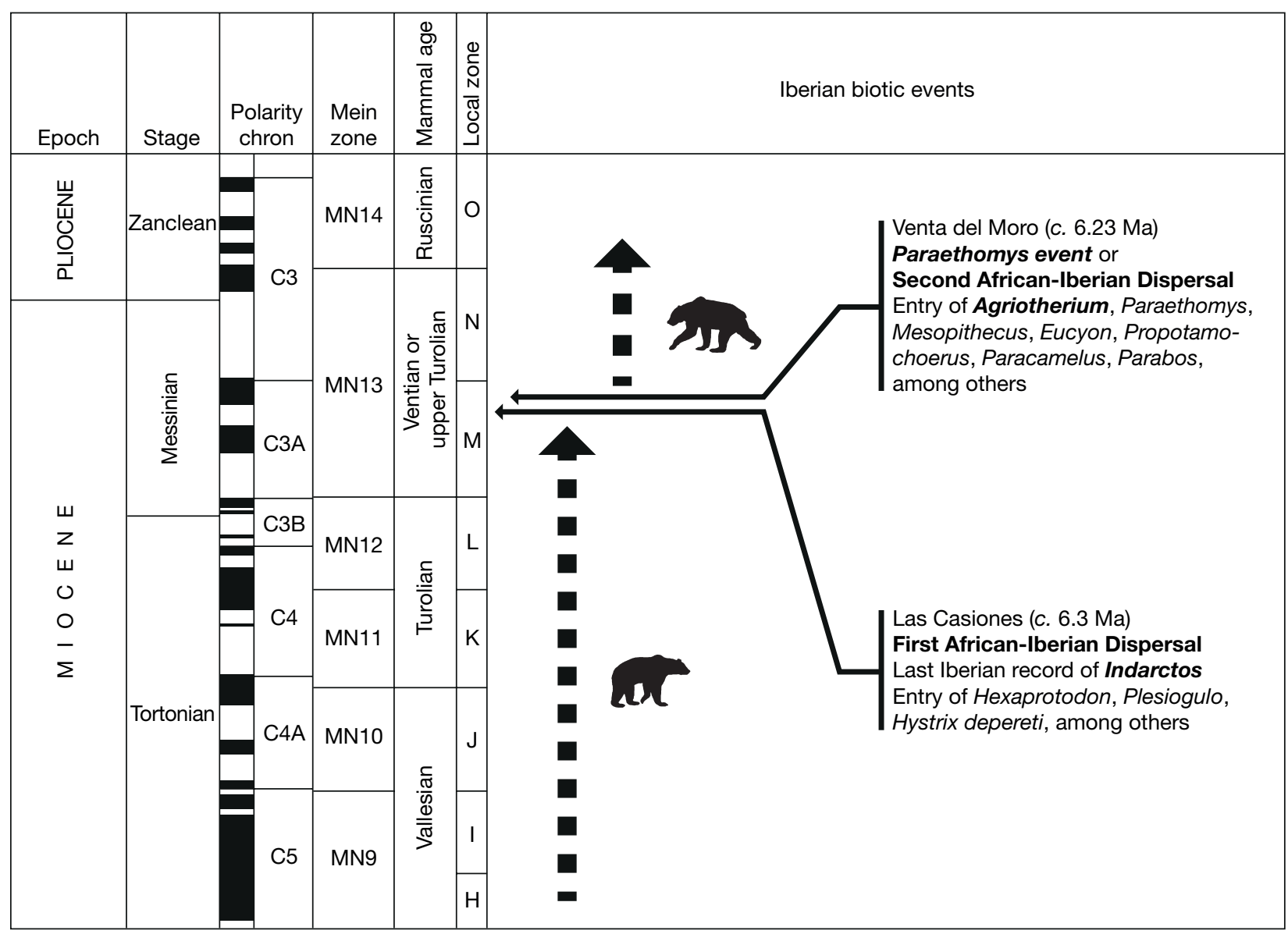

FIG. 8. - Biochronology showing the stratigraphic ranges of the genera Indarctos Pilgrim, 1913 and Agriotherium A. Wagner, 1837 in the Iberian Peninsula, related to the two biotic events recorded during the Messinian. Mammal ages and local zones according to Morales et al. 2013. Absolute age after Gibert et al. 2013.

the 'Third dispersal event' by Made et al. (2006). The fact that this faunal event has been evidenced, and named differently by different authors tells us of its importance.

The mammalian fauna with Agriotherium from Venta del Moro is, as far as large mammals are concerned, composed of a mixture of taxa already present in the Western European Turolian, together with a contingent of more than 50\% that appear first in the fossil record of the Iberian Peninsula (Morales et al. 2011), and who are immigrants from the east or from Africa. Thus, the Euroasiatic provenance of $A$. robles $i$ cannot be disregarded. Therefore, the replacement of Indarctos by Agriotherium could be linked to this great faunal renewal event, which we now know took place 250000 years before the onset of the Messinian Salinity Crisis (Agustí et al. 2006; Gibert et al. 2013) (Fig. 8).

\section{FINAL REMARKS}

Although some of the dental features may converge towards those present in some species of Agriotherium species, it seems clear that the studied dental remains represent a large-sized Indarctos, similar in both size and morphology to the syntype of I. punjabiensis. Moreover, the population from Las Casiones marks the upper range of the record of the genus Indarctos in the Iberian Peninsula and probably also in Europe. It belongs to the faunal assemblage prior to the entrance, at c. 6.23 Ma, of the rodent Paraethomys and many other immigrants, including the hemicyonid ursoid Agriotherium.

\section{Acknowledgements}

The authors of this paper would like to express our deep sadness at the passing of our beloved friend and colleague Stéphane, with whom we shared great moments, both during fieldwork and manuscript writing; we would have loved to have had many more moments together. Excavations at Las Casiones, preparation of fossils, and palaeontological research have been made possible thanks to the support of the Dirección General de Patrimonio Cultural, Gobierno de Aragón (Spain). The authors thank the Herrero family (owners of the property where the Las Casiones site is located), J. Esteban, M. Marco, and all members and volunteers from excavation and fossil preparation teams. This study is one of the palaeontological research projects subsidized by the Departamento de Educación, Cultura y Deporte-Gobierno de Aragón and Grupo de Investigación de Referencia E04_17R FOCONTUR cofinanciado por el Departamento de Innovación, Investigación y Universidad 
(Gobierno de Aragón) y fondos FEDER Aragón 2014-2020, "Construyendo Europa desde Aragón"; the Instituto Aragonés de Fomento. DH is researcher in formation in the FPU 2013 program granted by the Ministerio de Educación, Cultura y Deporte, Spain). The support of the DST-NFR Centre of Excellence in Palaeosciences (CoE-Pal) toward this research for A.V. (COE2018-09POST and COE2019-PD07) is hereby acknowledged. Opinions expressed and conclusions arrived at, are those of the authors and are not necessarily to be attributed to the CoE. This study was supported by the Spanish Research Projects CGL 2015-68333-P and CGL2016-76431-P (AEI/ FEDER, UE), the BSCH-UCM910607 of the Universidad Complutense de Madrid, the Research Groups CSIC 641538 and CAM-UCM 910607, and the Generalitat de Catalunya (CERCA Programme, and Beatriu de Pinós contract 2017 BP 00223 from AGAUR to JA).

\section{REFERENCES}

Abella J. 2011. - Indarctos arctoides Depéret, 1895 (Carnivora, Mammalia) del yacimiento vallesiense de Batallones 3 (cuenca de Madrid) [Indarctos arctoides Depéret, 1895 (Carnivora, Mammalia) from the vallesian locality of Batallones 3 (Madrid Basin)]. $\mathrm{PhD}$ dissertation, unpublished. Madrid: Universidad Autónoma de Madrid- Museo Nacional de Ciencias Naturales (CSIC) (in Spanish).

Abella J., Alba D. V., Robles J. M., Valenciano A., Rotgers C., Carmona R., Montoya P. \& Morales J. 2012. - Kretzoiarctos gen. nov., the oldest member of the giant panda clade. PLoS ONE 7: e48985. https://doi.org/10.1371/journal.pone.0048985

Abella J., Valenciano A., Pérez-Ramos A., Montoya P. \& MorALES J. 2013. - On the socio-sexual behaviour of the extinct ursid Indarctos arctoides: An approach based on its baculum size and morphology. PLoS ONE 8: e77711. https://doi.org/10.1371/ journal.pone.0073711

Abella J., Montoya P. \& Morales J. 2014. — Paleodiversity of the Superfamily Ursoidea (Carnivora, Mammalia) in the Spanish Neogene, related to environmental changes. Journal of Iberian Geology 40:11-18. https://doi.org/10.5209/rev_JIGE.2014.v40.n1.44083

Abella J., Pérez-Ramos A., Valenciano A., Alba D. M., Ercoli M. D., Hontecillas D., Montoya P. \& Morales J. 2015. — Tracing the origin of the panda's thumb. The science of Nature 102: 35. https://doi.org/10.1007/s00114-015-1286-3

Agustí J., Garcés M. \& Krijgsman W. 2006. — Evidence for African-Iberian exchanges during the Messinian in the Spanish mammalian recod. Palaeogeography, Palaeoclimatology, Palaeoecology 238: 5-14. https://doi.org/10.1016/j.palaeo.2006.03.013

ALCALÁ L. 1994. - Macromamíferos neógenos de la fosa de Alfambra-Teruel [Neogene macromammals from the Alfambra-Teruel grave]. Instituto de Estudios Turolenses, Museo Nacional de Ciencias Naturales - CSIC, Teruel, 554 p. (in Spanish).

AlCAlÁ L. \& Montoya P. 1998a. - Hystrix primigenia (Wagner, 1848) (Rodentia, Mammalia) del Turoliense superior (MN 13) de Las Casiones (Teruel, España) [Hystrix primigenia (Wagner, 1848) (Rodentia, Mammalia) from the Late Turolian (MN 13) of Las Casiones (Teruel, Spain)]. Revista Española de Paleontología 13: 139-147.

AlCalá L. \& Montoya P. 1998b. - Hexaprotodon crusafonti (Hippopotamidae, Mammalia) del Mioceno superior de El Arquillo (Fosa de Teruel) [Hexaprotodon crusafonti (Hippopotamidae, Mammalia) from the Late Miocene of El Arquillo (Teruel Grave)]. Boletin de la Real Sociedad Española de Historia Natural Sección Geológica 94: 93-100.
Alcalá L., Montoya P. \& Morales J. 1994. - New large mustelids from the Late Miocene of the Teruel Basin (Spain). Comptes rendus de l'Académie des Sciences, série II, 319: 1093-1100. https:// gallica.bnf.fr/ark:/12148/bpt6k58032150/f233.item

Alcalá l., Van Dam J., Luque L., Montoya P. \& Abella J. 2005. - Nuevos mamíferos vallesienses en Masía de La Roma (Cuenca de Teruel) [New Vallesian mammals from Masía de La Roma (Teruel Basin)]. Geogaceta 37: 199-202.

BARYSHNiKOV G. F. 2002. — Late Miocene Indarctos punjabiensis atticus (Carnivora, Ursidae) in Ukraine with survey of Indarctos records from the former USSR. Russian Journal of Theriology 1 : 83-89. https://doi.org/10.15298/rusjtheriol.01.2.02

Baryshnikov G. F. \& Tleuberdina P. A. 2017. — Late Miocene Indarctos (Carnivora: Ursidae) from the Karabulak Formation of the Kalmakpai river (Zaisan Depression, Eastern Kazakhstan). Proceedings of the Zoological Institute of the Russian Academy of Sciences 321: 3-9.

Bonis L. De, Abella J., Merceron G. \& Begun D. R. 2017. A new late Miocene ailuropodine (Giant Panda) from Rudabanya (North-central Hungary). Geobios 50: 413-421. https://doi. org/10.1016/j.geobios.2017.09.003

BowDICH T. E. 1821. - An Analysis of the Natural Classifications of Mammalia for Use of Students and Travellers. J. Smith, Paris, 115 p.

Bruijn H. De, DaAms R., Daxner-Höck G., Fahlbusch V., Ginsburg L., Mein P. \& Morales J. 1992. - Report of the RCMNS working group on fossil mammals, Reisensburg 1990. Newsletters on Stratigraphy 26: 65-118. https://doi.org/10.1127/ nos/26/1992/65

CERDEÑO E. 1989. - Revisión de la sistemática de los rinocerontes del Neógeno de España [Review of the Systematic of Rhinoceros from the Neogene of Spain]. [PhD dissertation]. Universidad Complutense, Madrid, $429 \mathrm{p}$.

Crusafont Pairó M. \& Kurtén B. 1976. — Bears and bear-dogs from the Vallesian of the Vallés-Penedés Basin, Spain. Acta Zoologica Fennica 144: 1-29.

DAMES W. 1883. - Über das Vorkommen von Hyaenarctos in den Pliocän-Ablagerungen von Pikermi bei Athen. Sitzungsberichte der Gesellschaft Naturforschender Freunde zu Berlin 1883 (8): 132139. https://biodiversitylibrary.org/page/8789424

DEPÉRET C. 1895. - Résultats des fouilles paléontologiques dans le Miocène supérieur de la colline de Montredon. Comptes rendus hebdomadaires des Séances de l'Académie des Sciences 121: 432-434. https://biodiversitylibrary.org/page/36256646

Domingo M. S., Domingo L., Abella J., Valenciano A., Badgley C. \& MORALES J. 2016. — Feeding ecology and habitat preferences of top predators from two Miocene carnivore-rich assemblages. Paleobiology 42: 489-507. https://doi.org/10.1017/pab.2015.50

FisCher [DE WALDHEIM] G. 1814. - Zoognosia tabulis synopticis illustrata. Vol. 3, 3rd ed. Nikolai Sergei Vsevolozsky, Mosquae, $732 \mathrm{p}$.

FLOWER W. H. 1869. - On the value of the characters of the base of the cranium in the classification of the order Carnivora, and on the systematic position of Bassaris and other disputed forms. Proceedings of the Zoological Society of London 1869: 4-37. https:// biodiversitylibrary.org/page/28662875

FriCK C. 1926. - The Hemicyoninae and an American Tertiary Bear. Bulletin of the American Museum of Natural History 56: 1-120. http://hdl.handle.net/2246/1321

GeraAds D., Kaya T. \& Mayda S. 2005. - Late Miocene large mammals from Yulafli, Thrace region, Turkey, and their biogeographic implications. Acta Palaeontologica Polonica 50 (3): 523-544.

Gibert L., SCOTt G. R., Montoya P., Ruiz-SÁncez F. J., Morales J., LUQUE L., ABELla J. \& LeRÍA M. 2013. — Evidence for an AfricanIberian mammal dispersal during the pre-evaporitic Messinian. Geology 41: 691-694. https://doi.org/10.1130/G34164.1

HendeY Q. B. 1972. - A Pliocene ursid from South Africa. Annals of the South African Museum 59: 115-132. https://biodiversitylibrary.org/page/40938928 
Hendey Q. B. 1980. — Agriotherium (Mammalia, Ursidae) from Langebaanweg, South Africa, and relationships of the genus. Annals of the South African Museum 81: 1-109. https://biodiversitylibrary.org/page/40751715

KRETZOI M. 1943. - Kochictis centennii n. g. n. sp., ein altertümlicher Creodonte aus dem Oberoligozän Siebenbürgens. Földtani Közlöny 73: 190-195.

LYDEKKER R. 1884. - Indian Tertiary and post-Tertiary Vertebrata. Part 6. Siwalik and Narbada Carnivora. Memoirs of the Geological Survey of India. Palaeontologia Indica 10: 178-363. https:// biodiversitylibrary.org/page/53674503

Made J. Van Der, Morales J. \& Montoya P. 2006. - Late Miocene turnover in the Spanish mammal record in relation to palaeoclimate and the Messinian Salinity Crisis. Palaeogeography, Palaeoclimatology, Palaeoecology 238: 228-246. https://doi. org/10.1016/j.palaeo.2006.03.030

Mein P. 1990. — Updating of MN zones, in Lindsay E. H., FAHLBUSCH V. \& MEIN P. (eds), European Neogene Mammal Chronology. Plenum Press, New York: 73-90. https://doi.org/10.1007/9781-4899-2513-8_6

Monescillo M. F. G., Salesa M. J., Antón M., Siliceo G. \& Morales J. 2014. - Machairodus aphanistus (Felidae, Machairodontinae, Homotherini) from the Late Miocene (Vallesian, MN10) site of Batallones-3 (Torrejón de Velasco, Madrid, Spain). Journal of Vertebrate Paleontology 34: 699-709. https://doi.org/1 0.1080/02724634.2013.804415

MonTOYA P. 1994. - Los macromamíferos del Mioceno superior del área de Crevillente (Alicante) [The macromammals from Late Miocene of the area of Crevillente (Alicante)]. [PhD dissertation] Valencia: Universitat de València (in Spanish).

Montoya P., Alcalá L. \& Morales J. 2001. — Indarctos (Ursidae, Mammalia) from the Spanish Turolian (Upper Miocene). Scripta Geologica 122:123-151.

Montoya P., Morales J., Robles F., Abella J., Benavent J. V., Marín M. D. \& Ruiz SÁnchez F. J. 2006. - Las nuevas excavaciones (1995-2006) en el yacimiento del Mioceno final de Venta del Moro, Valencia [The new excavations (1995-2006) in the Late Miocene locality of Venta del Moro]. Estudios Geológicos 62: 313-326 (in Spanish). https://doi.org/10.3989/egeol.0662128

Morales J. 1984. - Venta del Moro: su macrofauna de mamiferos y biostratigrafía continental del Mioceno terminal mediterráneo. Editorial Universidad Complu- tense, Madrid, $340 \mathrm{p}$ (in Spanish).

Morales J. \& Aguirre E. 1976. - Carnívoros de Venta del Moro (Valencia) [Carnivorans from Venta del Moro (Valencia)]. Trabajos sobre Neógeno-Cuaternario 5: 31-74 (in Spanish).

Morales J., Montoya P. \& Abella J. 2011. — Venta del Moro: un yacimiento clave para conocer la historia del límite Mio-Plioceno en el área mediterránea [Venta del Moro: a key locality to know the history of the Mio-Pliocene limit in the Mediterranean area]. Isurus 4: 60-71 (in Spanish).

Morales J., Peláez-Campomanes P., Abella J., Montoya P., Gibert L., Scott G., Cantalapiedra J. L. \& Sanisidro O. 2013. - The Ventian mammal age (latest Miocene): present state. Spanish Journal of Palaeontology 28: 149-160.

Pesquero M. D. 2003. - Hipparion del Turoliense superior de Las Casiones (Fosa de Teruel) [Hipparion from Late Turolian from Las Casiones (Teruel Grave)]. Coloquios de Paleontología Vol. Ext. 1: 511-548 (in Spanish).

PILGRIM G. E. 1913. - The correlation of the Siwaliks with the Mammal Horizons of Europe. Records of the Geological Survey of India 43: 264-326.

PILGRIM G. E. 1914. - Further description of Indarctos salmontanus Pilgrim, the new genus of bear from the Middle Siwaliks, with some remarks on the fossil indian Ursidae. Records of the Geological Survey of India 44: 225-233.

QIU Z.-X., DenG T. \& WANG B.-Y. 2014. - A Late Miocene Ursavus skull from Guanghe, Gansu, China. Vertebrata PalAsiatica 52: 265-302.

Salesa M. J., Pesquero M. D., Siliceo G., Antón M., Alcalá L. \& MorALES J. 2012. - A rich community of felidae (Mammalia, Carnivora) from the late Miocene (Turolian, MN 13) site of Las Casiones (Villalba Baja, Teruel, Spain). Journal of Vertebrate Paleontology 32: 658-676. https://doi.org/10.1080/02724634. 2012.649816

TEDFORD R. H. 1976. - Relationship of pinnipeds to other carnivores (Mammalia). Systematic Zoology 25: 363-374. https:// doi.org/10.2307/2412511

TOBIEN H. 1955. - Neue und wenig bekannte Carnivoren aus den Unterpliozänen Dinotheriensanden Rheinhessens. Notizblatt des Hessischen L.-Amts für Bodenforshung zu Wiesbaden 83: 7-31.

VAN DAM J. A. 1997. - The small mammals from the Upper Miocene of the Teruel-Alfambra region (Spain): paleobiology and paleoclimatic reconstructions. Geologica Ultraiectina 156: 1-204.

Van Dam J. A., Alcalá L., Alonso Zarza A., Calvo J. P., Garcés M. \& Krijgsman W. 2001. - The upper Miocene mammal record from the Teruel-Alfambra region (Spain). The MN system and continental stage/age concepts discussed. Journal of Vertebrate Paleontology 21:367-385. https://doi.org/10.1671/02724634(2001)021[0367:TUMMRF]2.0.CO;2

Van Dam J. A., Abdul Aziz H., Álvarez-Sierra M. A., Hilgen F. J., Van Den Hoek Ostende L., Lourens L. J., Mein P., Van DeR Meulen A. J. \& Peláez-Campomanes P. 2006. — Long-period astronomical forcing of mammal turnover. Nature 443: 687-691. https://doi.org/10.1038/nature05163

VAN WeERS D. J. \& ROOK L. 2003. - Turolian and Ruscinian porcupines (genus Hystrix, Rodentia) from Europe, Asia and North Africa. Paläontologische Zeitschrift 77: 95-113. https:// doi.org/10.1007/BF03004562

Villalta y Comella J. F. DE \& Crusafont pairó M. 1943. - Indarctos vireti, nova sp., un nuevo úrsido del grupo de los Hemiciónidos del Mioceno superior del Vallés-Penedés [Indarctos vireti, nova sp., a new ursid of the hemicyonids group from Late Miocene from Vallés-Penedés]. Consejo Superior de Investigaciones Cientificas 1943: 45-62 (in Spanish).

Villalta y Comella J. F. DE \& Crusafont Pairó M. 1948. Nuevas aportaciones al conocimiento de los carnívoros pontienses del Vallés-Penedés [New data to the knowledge of the pontian carnivorans from Vallés-Penedés]. Publicaciones del Instituto de Geologia de Barcelona, Miscelánea Almera 7: 81-121 (in Spanish).

VIRANTA S. 2004. - Habitat preferences of European Middle Miocene omnivorous ursids. Acta Palaeontologica Polonica 49: 325-327.

WAGNER A. 1837. — First Part of the nineteenth Volume of Asiatic Researches; or Transactions of the Society, instituted in Bengal, for enquiring into the History, etc. [book review]. Gelehrte Anzeigen 5 (170): 334-336.

Weithofer A. 1888. — Beiträge zur Kenntniss der Fauna von Pikermi bei Athen. Beiträge zur Paläntologie und Geologie Österreich-Ungarns und des Orients 6: 225-292.

ZdANSKY O. 1924. - Jungtertiäre Carnivoren Chinas. Palaeontologia Sinica, ser. C, 2: 1-155. 